\title{
Methods of estimating land resources of Ukraine in the conditions of land market formation for the purposes of sustainable development
}

\author{
Volodymyr Shvets ${ }^{1, *}$, Nataliia Mishchuk ${ }^{1}$, and Oksana Novostavska $^{1}$ \\ ${ }^{1}$ Ivan Franko National University of Lviv, 1, Universytetska str., 79000 Lviv, Ukraine
}

\begin{abstract}
Sustainable development of Ukraine is not possible without the functioning of a civilized land market.The Ukrainian government has formed a set of amendments to the Land Code and other laws and provides for the start of the land market in mid-2021. However, the mechanism for assessing land resources is not sufficiently developed and requires saturation of methodological and information support. The article proposes methods of land valuation and methods of determining its investment attractiveness for investors. The formation of the information base for the assessment of land resources is possible only by applying a retrospective method of analysis of data generated on Ukrainian lands in a market economy, due to the peculiarities of the interrupted evolutionary process. In the analysis of investment attractiveness of land assets, the main focus is on the possibilities of applying the method of standardization of indicators. Application of the offered methods will promote creation in Ukraine of the effective market of the earth with harmonious maintenance of interests of the Ukrainian people and investors. The purpose of this article is to study the methods of valuation of land assets of Ukraine to determine their investment attractiveness in the formation of the land market.
\end{abstract}

\section{Introduction}

The urgency of creating a land market in Ukraine is beyond doubt if sustainable development is chosen as the state's priority strategy. Despite some controversial issues that arose rather from the pursuit of narrowly party political interests and ambitions, it is generally accepted that only a fully civilized and transparent land market will ensure the effective functioning of a market economy in Ukraine. After all, as a result of the creation of the land market, society will receive a number of necessary benefits, namely: revives the process of buying and selling agricultural land, which will create conditions for their effective use; the activity and interest of financial capital in investments in agricultural production will increase; there will be an opportunity for agricultural producers to attract affordable and cheap mortgage loans, and banks will receive guarantees of their return; Ukraine will strengthen its position on the world market as an efficient exporter of grain

\footnotetext{
* Corresponding author: shwe@ukr.net
} 
and food. However, an important problem in the implementation of these tasks is the lack of regulatory and scientific sources of effective methodological and information support for a real initial assessment of land resources in Ukraine. Therefore, the main purpose of the study is to highlight the inaccessible experience of land valuation in Ukrainian lands and the possibility of applying methods of retrospective analysis and standardization of indicators for the formation of methods of initial (regulatory) land valuation. Achieving this goal involves solving the following tasks: analysis of the current situation on the eve of the introduction of the land market in Ukraine; disclosure of methods of statistical research on land valuation in the early twentieth century; conducting a retrospective analysis of the valuation of land assets in the Ukrainian lands based on the results of statistical surveys during 1903-1908; substantiation of usefulness and disclosure of methods of application of data standardization to determine the investment attractiveness of land assets in Ukraine; assessment of the investment attractiveness of land resources of Ukraine in terms of individual regions, taking into account the interests of investors.

\section{Material and methods}

The adoption by the Verkhovna Rada of Ukraine of the strategically important Law on Amendments to Legislative Acts on Deregulation of Land Relations [1] is the culmination of the implementation of land reform and the beginning of the functioning of the land market on the first of July, 2021.Amendments to the Land Code of Ukraine [2] and other legislative acts are aimed at improving the management system for deregulation of land relations. As you know, more than 3,000 amendments are aimed at simplifying land registration procedures and combating corruption schemes that hinder the creation of a civilized land market.These changes concern four areas, namely: transfer of rights to dispose of land resources to local governments through the mechanism of land auctions; elimination of corruption schemes, where the main changes relate to the removal of the State Service of Ukraine for Geodesy, Cartography and Cadastre from the disposal of land and control over their use, which will reduce the risks of abuse in land relations; removal of bureaucratic barriers by eliminating unnecessary and approvals related to the formation of land; creation of a transparent and open land market in Ukraine, including the provision of opportunities for foreign individuals and legal entities to purchase non-agricultural land plots free of development outside settlements.

As a result of these innovations, it is planned to create conditions for openness and accessibility of land management documentation in electronic form. And in order to ensure the publicity of land use, a monitoring system is being introduced, which will be conducted every three months, which will allow obtaining data on the number of land assets owned by specific individuals and legal entities. In total, land reform includes about a dozen bills, the main purpose of which is to ensure transparent management of land resources, among which the key issue for the proper functioning of the land market is the launch of land auctions. After all, it is land auctions that allow to form fair prices for land assets, in contrast to the existing and legally established expert and regulatory assessments of land [3]. In turn, a fair price is a price that is formed between interested, informed and independent market participants ensures the efficient use of land assets and prevents the existence of corruption schemes. Among these conditions, the most difficult, in the conditions of Ukraine, is to achieve information support, which can always be decisive.

A striking example of the information impact on the reduction of capital investment in the agro-industrial sectors of Ukraine's economy were the expectations of changes in connection with land reform [4]. Thus, in 2020, such investments amounted to UAH 36 billion, which was $53.3 \%$ of the corresponding figure for 2019 . 
Such information shows that 2020 has become an investment and crisis year for the agricultural sector of Ukraine, similar to the financial crisis of 2009. Among the factors the reasons for refusing to implement investment projects, in our opinion, was the expectation of the beginning of the functioning of the market of agricultural land assets. The important role of information support for potential participants in the land market has constantly attracted the attention of scientists, which is reflected in many studies [5-9].

Research materials indicate the existence of two main areas of discussion: the first concerns the organization and methods of analysis of investment attractiveness of territories; the second direction is related to the method of valuation of land assets. The greatest attention and prospects for further research, in our opinion, require a combination of areas that include methods of valuing land assets and analysis of investment attractiveness.

The second area of research, as mentioned above, concerns the analysis of the investment attractiveness of today's agricultural land resources of Ukraine. The information provided for such analysis is the statistical data that are publicly available on the website of the State Statistics Committee. The analysis of the investment attractiveness of the regions of Ukraine for investors specializing in agricultural production will include, for example, the use of the following indicators: area of crops and harvesting of various cereals; production volumes and harvesting of wheat and cereals and legumes; harvesting corn for grain and yield, etc.

At the same time, the multifaceted nature of these indicators complicates the process of analyzing the most investment-attractive regions, as one region may have higher yields of some crops and other crops, while the neighboring region, on the contrary, has lower yields of other crops and higher yields. Therefore, among the variety of analysis methods, the method of standardization of indicators was preferred [8]. This method allows you to use a variety of diverse indicators, but which characterize the various aspects of the research topic in terms of preferences and interests of investors.

\section{Theory/calculation}

The use of retrospective analysis methods usually makes it possible to determine the causal relationships between phenomena and processes that have already occurred. That is, we can no longer influence the results of retrospective analysis, we can not adjust them, in contrast to the operational analysis, which allows for corrective action and influence the final performance indicator. At the same time, the advantage of retrospective analysis is the ability to study economic phenomena and processes, which allows you to apply all possible analytical techniques and obtain comprehensive information about the studied trends. The results of retrospective analysis are used both for interpolation of missing data and for extrapolation in strategic studies and forecasts.In our study, given the lack of modern materials for market valuation of land resources in Ukraine, retrospective analysis of statistical surveys is the only way to get the results of the real value of land assets, this is the first. And secondly, the results of the retrospective analysis will contribute to the formation of basic or regulatory prices for land resources in Ukraine. Using the results of statistical observations on the valuation of land assets in market relations [10], we can recalculate the lowest and highest valuation of Ukrainian lands according to the tried and tested method, taking into account the gold content of the ruble [8] and today's gold value [12].

The second direction of the study - the analysis of the investment attractiveness of individual regions using the method of standardization of indicators has partially been tested in the data of 2018 [8]. 
However, the passage of time requires not only to apply the capabilities of the method of standardization of indicators on the example of new statistics, but also to show much greater prospects for its use.

The main purpose of the method of standardization of indicators is to analyze the selected set of indicators that characterize the individual phenomena and processes taking place in the regions of Ukraine in a particular market segment, to determine the most attractive in terms of investment. The content of the method of standardization of indicators is the mathematical processing of indicators that best characterize a particular phenomenon but are diverse in value because they reflect the parameters of this phenomenon in different incomparable measures. In turn, mathematical processing provides bringing these indicators to their comparative form. First, the average value for each numerical series is determined, then the difference between the deviations of each indicator of the region from its mean is calculated and find the quadratic deviation by which the initial value of the initial indicator is divided.

After that, the standardized indicators are summarized for each region separately and on the basis of the obtained sum of points the regions are ranked according to the value of these points. The resulting ranked series can be divided into zones of investment attractiveness (three or five) and assign their respective names according to the level of evaluation.

The application of the method of standardization of indicators involves the use of the following formulas:

$$
\begin{aligned}
& X_{i}^{1}=\frac{X_{1}}{S}, \text { for } i=\overline{1, n} \\
& X_{i}^{1}=\frac{X_{i}^{2}}{S}, \text { for } i=\overline{1, n} \\
& X_{i}^{1}=\frac{\left(X_{i}-\bar{X}_{i}\right)}{S}, \text { for } i=\overline{1, n}
\end{aligned}
$$

where: $X_{\mathrm{i}}^{1}$ - standardized i-th implementation of the variable; $S$ - standard deviation of the variable; $n-$ is the number of studied objects.

The analysis of investment attractiveness of land resources in terms of regions of Ukraine begins with the choice of statistical indicators. The formation of the information base for this analysis is the processing of statistical data on the official website of the State Statistics Committee of Ukraine [11]. The criteria for selecting a set of indicators for analysis are the interests of the investor. For example, let's assume that the business interests of a potential investor are large areas of wheat, legumes and corn, because it is a large company and specializes in the production of these crops. It is known that the group of cereal legumes includes peas, beans, soybeans, chickpeas, fodder beans, etc., which belong to the legume family.

These cultures are characterized by the highest protein content.Among the statistical indicators according to the following criteria, the most suitable for information support of the analysis are: wheat harvest; harvesting of cereals and legumes; harvesting corn for grain.

These three indicators are represented by such parameters as the area harvested in thousands of hectares and the volume of production in thousands of quintals [11]. According to these criteria, data were selected for three indicators as of 1.12.2020, which are presented in the form of Table 1.

As can be seen from Table 1, the highest indicators on the areas of wheat have the following areas: Zaporizhzhia (665,2 thousand hectares), Odessa (545,1 thousand hectares) and Kharkiv (534,1 thousand hectares), while the volume of harvested wheat ranks first 
Kharkiv region (27179,2 thousand quintals), in second place Zaporizhzhia region (20960,4 thousand quintals), and in third place Dnipropetrovsk region (19870,1 thousand quintals). According to the indicators of grain and legume harvest areas, Dnipropetrovsk region is in the first place $(1093,4$ thousand hectares), Odessa region is in the second place $(1046,8$ thousand hectares), and Kharkiv region is in the third place (1008,8 thousand hectares). For these crops in terms of production of cereals and legumes, the highest rates are: Poltava region (50492 thousand quintals); Chernihiv region (50075,3 thousand quintals), Sumy region (48563,8 thousand quintals). The inconsistency and diversity of indicators indicates the presence and effect of factors of various kinds, in particular, it may be a factor of specialization of regions, climatic conditions.

Therefore, the use of the method of standardization of indicators once again confirms its usefulness.

Table 1. Information base for the analysis of investment attractiveness of harvest areas and production volumes of wheat, legumes and corn in Ukraine in 2020.

\begin{tabular}{|c|c|c|c|c|c|c|}
\hline \multirow[b]{2}{*}{ Region } & \multicolumn{2}{|c|}{$\begin{array}{l}\text { Harvesting of wheat as of } \\
01 \text { December } 2020\end{array}$} & \multicolumn{2}{|c|}{$\begin{array}{l}\text { Harvesting of cereal and } \\
\text { leguminous crops as of } \\
01 \text { December } 2020\end{array}$} & \multicolumn{2}{|c|}{$\begin{array}{l}\text { Harvesting of maize for } \\
\text { grain as of } 01 \text { December } \\
2020\end{array}$} \\
\hline & $\begin{array}{l}\text { harvested } \\
\text { area, } \\
\text { thsd.ha }\end{array}$ & $\begin{array}{l}\text { volume of } \\
\text { production, } \\
\text { thsd. } \\
\text { centner }\end{array}$ & $\begin{array}{l}\text { harvested } \\
\text { area, } \\
\text { thsd.ha }\end{array}$ & $\begin{array}{l}\text { volume of } \\
\text { production, } \\
\text { thsd. } \\
\text { centner }\end{array}$ & $\begin{array}{l}\text { harvested } \\
\text { area, } \\
\text { thsd.ha }\end{array}$ & $\begin{array}{l}\text { volume of } \\
\text { production, } \\
\text { thsd. } \\
\text { centner }\end{array}$ \\
\hline Vinnytsia & 315,9 & 13889,1 & 856,5 & 40675,3 & 429,8 & 22677 \\
\hline Volyn & 164,5 & 7389,6 & 298,5 & 13347,1 & 30 & 2872,3 \\
\hline Dnipropetrovsk & 508 & 19870,1 & 1093,4 & 35732,6 & 307,5 & 7415,6 \\
\hline Donetsk & 352,3 & 14055,8 & 568,6 & 20143,5 & 58,6 & 1796,9 \\
\hline Zhytomyr & 149,9 & 6392,1 & 467,6 & 22864,9 & 194,5 & 13065,9 \\
\hline Zacarpattia & 24 & 832,3 & 70,8 & 2896,4 & 41,6 & 1922,4 \\
\hline Zaporizhzhia & 665,2 & 20960,4 & 983,4 & 29962,5 & 33,5 & 1639,1 \\
\hline $\begin{array}{l}\text { Ivano- } \\
\text { Frankivsk }\end{array}$ & 63,6 & 2905,2 & 146,5 & 7955,5 & 42,6 & 3483,7 \\
\hline Kyiv & 182,3 & 7960,1 & 624,8 & 28980,3 & 342,5 & 17401,1 \\
\hline Kirovohrad & 311,9 & 11489,6 & 839,5 & 26712,8 & 382,1 & 10471,3 \\
\hline Lugansk & 269 & 10351,7 & 391,4 & 13765,7 & 62,8 & 1849,9 \\
\hline Lviv & 173,8 & 8087 & 280,2 & 13939,5 & 41,1 & 3395,4 \\
\hline Mykolaiv & 429 & 11797,6 & 877,8 & 23955,6 & 112,8 & 3166,7 \\
\hline Odesa & 545,1 & 10198,4 & 1046,8 & 20207,1 & 133,8 & 3731,6 \\
\hline Poltava & 228,4 & 10438,2 & 988,9 & 50492 & 650,7 & 36234 \\
\hline Rivne & 110,4 & 4971 & 252,5 & 12646,4 & 51,2 & 4689,4 \\
\hline Sumy & 176,4 & 9456,6 & 670,9 & 48563,8 & 416,1 & 36222,7 \\
\hline Ternopil & 214,6 & 10500,8 & 445,7 & 25555,3 & 108,3 & 10004,8 \\
\hline Kharkiv & 534,1 & 27179,2 & 1008,8 & 48497,6 & 275,5 & 14086,7 \\
\hline Kherson & 490,8 & 16061,6 & 774,9 & 27321,5 & 45,2 & 3693,4 \\
\hline Khmelnytsky & 232,4 & 10991,3 & 576,1 & 38146,9 & 238 & 23139,2 \\
\hline Cherkasy & 175,5 & 7749,6 & 651,6 & 25339,8 & 407,1 & 15188,8 \\
\hline Chernivtsi & 40,1 & 1542,6 & 116,8 & 5668 & 53,8 & 3338,5 \\
\hline Chernihiv & 158,2 & 7691,2 & 727,1 & 50075,3 & 468,3 & 39113,5 \\
\hline Ukraine & 6515,4 & 252761,1 & 14759,1 & 633445,4 & 4927,4 & 280599,9 \\
\hline $\bar{x}$ & 271,5 & 10531,7 & 615,0 & 26393,6 & 205,3 & 11691,7 \\
\hline
\end{tabular}

After selecting statistical indicators in order to apply the method of their standardization to analyze the investment attractiveness of land resources in terms of regions of Ukraine, we perform calculations according to the above formulas (1-3). 
Table 2. Standardization of indicators of harvest areas and wheat production in Ukraine in 2020.

\begin{tabular}{|l|c|c|c|c|c|c|}
\hline \multirow{2}{*}{ Region } & \multicolumn{5}{|c|}{ Harvesting of wheat a of 01 December 2020 } \\
\cline { 2 - 7 } & \multicolumn{2}{|c|}{ harvested area, thsd.ha } & \multicolumn{3}{c|}{ volume of production, thsd. centner } \\
\cline { 2 - 7 } & $\left(x_{i}-\bar{x}\right)$ & $\left(x_{i}-\bar{x}\right)^{2}$ & $x_{i} / S$ & $\left(x_{i}-\bar{x}\right)$ & $\left(x_{i}-\bar{x}\right)^{2}$ & $x_{i} / S$ \\
\hline Vinnytsia & 44,4 & 1973,6 & 1,85 & 3357,4 & 11272050,83 & 2,33 \\
\hline Volyn & $-107,0$ & 11443,7 & 0,96 & $-3142,1$ & 9872870,963 & 1,24 \\
\hline Dnipropetrovsk & 236,5 & 55944,1 & 2,97 & 9338,4 & 87205481,1 & 3,34 \\
\hline Donetsk & 80,8 & 6532,7 & 2,06 & 3524,1 & 12419192,71 & 2,36 \\
\hline Zhytomyr & $-121,6$ & 14780,5 & 0,88 & $-4139,6$ & 17136391,65 & 1,07 \\
\hline Zacarpattia & $-247,5$ & 61243,9 & 0,14 & $-9699,4$ & 94078602,85 & 0,14 \\
\hline Zaporizhzhia & 393,7 & 155019,4 & 3,89 & 10428,7 & 108757523 & 3,52 \\
\hline Ivano-Frankivsk & $-207,9$ & 43212,0 & 0,37 & $-7626,5$ & 58163692,91 & 0,49 \\
\hline Kyiv & $-89,2$ & 7952,2 & 1,06 & $-2571,6$ & 6613190,85 & 1,34 \\
\hline Kirovohrad & 40,4 & 1634,2 & 1,82 & 957,9 & 917548,4627 & 1,93 \\
\hline Lugansk & $-2,5$ & 6,1 & 1,57 & $-180,0$ & 32404,50016 & 1,74 \\
\hline Lviv & $-97,7$ & 9540,4 & 1,02 & $-2444,7$ & 5976619,208 & 1,36 \\
\hline Mykolaiv & 157,5 & 24814,1 & 2,51 & 1265,9 & 1602471,163 & 1,98 \\
\hline Odesa & 273,6 & 74870,6 & 3,18 & $-333,3$ & 111097,2227 & 1,71 \\
\hline Poltava & $-43,1$ & 1855,5 & 1,33 & $-93,5$ & 8744,587656 & 1,75 \\
\hline Rivne & $-161,1$ & 25945,2 & 0,64 & $-5560,7$ & 30921523,51 & 0,83 \\
\hline Sumy & $-95,1$ & 9039,3 & 1,03 & $-1075,1$ & 1155866,888 & 1,59 \\
\hline Ternopil & $-56,9$ & 3234,8 & 1,25 & $-30,9$ & 955,5826563 & 1,76 \\
\hline Kharkiv & 262,6 & 68971,9 & 3,12 & 16647,5 & 277138840,1 & 4,56 \\
\hline Kherson & 219,3 & 48103,5 & 2,87 & 5529,9 & 30579655,76 & 2,70 \\
\hline Khmelnytsky & $-39,1$ & 1526,9 & 1,36 & 459,6 & 211220,6702 & 1,85 \\
\hline Cherkasy & $-96,0$ & 9211,2 & 1,03 & $-2782,1$ & 7740149,963 & 1,30 \\
\hline Chernivtsi & $-231,4$ & 53534,4 & 0,23 & $-8989,1$ & 80804143,54 & 0,26 \\
\hline Chernihiv & $-113,3$ & 12831,2 & 0,92 & $-2840,5$ & 8068511,263 & 1,29 \\
\hline \multicolumn{1}{|c|}{ Sum } & & $\mathbf{7 0 3 2 2 1 , 0}$ & & & $\mathbf{8 5 0 7 8 8 7 4 9 , 2 1}$ & \\
\hline & & $\mathbf{1 7 1 , 1 7}$ & & & $\mathbf{5 9 5 3 , 9 5}$ & \\
\hline
\end{tabular}

For convenience and data organization, it is advisable to use three analytical tables (Table 2-4).

According to tables (2-4) it is possible to determine the results of investment attractiveness of each region of Ukraine by summing each standardized indicator of the corresponding region.

\section{Results and discussion}

The results of a retrospective analysis of the valuation of land assets during 1903-1908 on Ukrainian lands, revealed the lowest prices in the Volyn province (62.8 rubles), which in terms of today's value of gold is equivalent to 74,435 hryvnias. The highest price of land assets was recorded in the Kherson province (296.6 rubles), which in a similar way is equal to the amount of 351552 hryvnia. 
Table 3. Standardization of indicators of harvest areas and production volumes of legumes and corn in Ukraine in 2020.

\begin{tabular}{|l|c|c|c|c|c|c|}
\hline \multirow{2}{*}{ Region } & \multicolumn{5}{|c|}{ Harvesting of cereal and leguminous crops as of 01 December 2020 } \\
\cline { 2 - 7 } & \multicolumn{4}{|c|}{ harvested area, thsd.ha } & \multicolumn{3}{c|}{ volume of production, thsd. centner } \\
\cline { 2 - 7 } & $\left(x_{i}-\bar{x}\right)$ & $\left(x_{i}-\bar{x}\right)^{2}$ & $x_{i} / S$ & $\left(x_{i}-\bar{x}\right)$ & $\left(x_{i}-\bar{x}\right)^{2}$ & $x_{i} / S$ \\
\hline Vinnytsia & 241,5 & 58340,4 & 2,78 & 14281,7 & 203968145,0 & 2,92 \\
\hline Volyn & $-316,5$ & 100148,5 & 0,97 & $-13046,5$ & 170210075,0 & 0,96 \\
\hline Dnipropetrovsk & 478,4 & 228902,4 & 3,55 & 9339,0 & 87217699,3 & 2,56 \\
\hline Donetsk & $-46,4$ & 2149,5 & 1,85 & $-6250,1$ & 39063229,2 & 1,44 \\
\hline Zhytomyr & $-147,4$ & 21715,7 & 1,52 & $-3528,7$ & 12451429,6 & 1,64 \\
\hline Zacarpattia & $-544,2$ & 296112,8 & 0,23 & $-23497,2$ & 552116449,7 & 0,21 \\
\hline Zaporizhzhia & 368,4 & 135746,2 & 3,19 & 3568,9 & 12737344,6 & 2,15 \\
\hline Ivano-Frankivsk & $-468,5$ & 219457,1 & 0,48 & $-18438,1$ & 339961995,1 & 0,57 \\
\hline Kyiv & 9,8 & 96,8 & 2,03 & 2586,7 & 6691232,5 & 2,08 \\
\hline Kirovohrad & 224,5 & 50417,1 & 2,72 & 319,2 & 101915,2 & 1,92 \\
\hline Lugansk & $-223,6$ & 49980,2 & 1,27 & $-12627,9$ & 159462806,1 & 0,99 \\
\hline Lviv & $-334,8$ & 112065,9 & 0,91 & $-12454,1$ & 155103569,0 & 1,00 \\
\hline Mykolaiv & 262,8 & 69083,6 & 2,85 & $-2438,0$ & 5943640,8 & 1,72 \\
\hline Odesa & 431,8 & 186483,6 & 3,40 & $-6186,5$ & 38272266,7 & 1,45 \\
\hline Poltava & 373,9 & 139829,3 & 3,21 & 24098,4 & 580734890,8 & 3,62 \\
\hline Rivne & $-362,5$ & 131379,1 & 0,82 & $-13747,2$ & 188984362,2 & 0,91 \\
\hline Sumy & 55,9 & 3129,0 & 2,18 & 22170,2 & 491519615,6 & 3,48 \\
\hline Ternopil & $-169,3$ & 28649,8 & 1,45 & $-838,3$ & 702677,0 & 1,83 \\
\hline Kharkiv & 393,8 & 155108,0 & 3,27 & 22104,0 & 488588658,0 & 3,48 \\
\hline Kherson & 159,9 & 25580,0 & 2,52 & 927,9 & 861075,7 & 1,96 \\
\hline Khmelnytsky & $-38,9$ & 1510,3 & 1,87 & 11753,3 & 138141040,3 & 2,74 \\
\hline Cherkasy & 36,6 & 1342,3 & 2,12 & $-1053,8$ & 1110406,6 & 1,82 \\
\hline Chernivtsi & $-498,2$ & 248165,9 & 0,38 & $-20725,6$ & 429548768,2 & 0,41 \\
\hline Chernihiv & 112,1 & 12574,8 & 2,36 & 23681,7 & 560824888,4 & 3,59 \\
\hline & & $\mathbf{2 2 7 7 9 6 8 , 2}$ & & & $\mathbf{4 6 6 4 3 1 8 1 8 0 , 8}$ & \\
\hline \multicolumn{1}{|c|}{ Sum } & $\mathbf{3 0 8 , 0 8}$ & & & $\mathbf{1 3 9 4 0 , 8 2}$ & \\
\hline
\end{tabular}

As a result of applying the method of standardization of indicators, we rank the regions of Ukraine by the sum of their points, which is the basis for the separation of three zones (Table 5).

As can be seen from the table. 5, we received an answer to the question of which of the studied areas have the highest parameters, in accordance with the selected indicators of the studied phenomenon, and which of them are in the area of least interest of a potential investor. As a result, the ranking of regions of Ukraine by the sum of scores of standardized indicators gives grounds to identify three main zones (Table 5):

1. Zone of strategic investment attractiveness. This includes seven regions, namely: Kharkiv, Poltava, Dnipropetrovsk, Vinnytsia, Chernihiv, Sumy and Zaporizhia with the sum of points from 17,22 to 13,08 .

2. Zone of average investment attractiveness. This zone includes 11 oblasts, namely: Kirovohrad, Khmelnytsky, Odesa, Kherson, Mykolaiv, Kyiv, Cherkasy, Donetsk, Ternopil, Zhytomyr and Luhansk with the number of points from 11,46 to 6,08.

3. Zone of low investment attractiveness. This includes the other six oblasts, namely: Lviv, Volyn, Rivne, Ivano-Frankivsk, Chernivtsi, Zakarpattia, which received from 4,81 to 1,12 points. 
Table 4. Standardization of indicators of harvest areas and volumes of corn production in 2020.

\begin{tabular}{|l|c|c|c|c|c|c|}
\hline \multirow{2}{*}{ Region } & \multicolumn{6}{|c|}{ Harvesting of maize for grain as of 01 December 2020 } \\
\cline { 2 - 7 } & \multicolumn{4}{|c|}{ harvested area, thsd.ha } & \multicolumn{2}{c|}{ volume of production, thsd. centner } \\
\cline { 2 - 7 } & $\left(x_{i}-\bar{x}\right)$ & $\left(x_{i}-\bar{x}\right)^{2}$ & $x_{i} / S$ & $\left(x_{i}-\bar{x}\right)$ & $\left(x_{i}-\bar{x}\right)^{2}$ & $x_{i} / S$ \\
\hline Vinnytsia & 224,5 & 50396,5 & 2,44 & 10985,3 & 120677640 & 1,96 \\
\hline Volyn & $-175,3$ & 30733,0 & 0,17 & $-8819,4$ & 77781154,91 & 0,25 \\
\hline Dnipropetrovsk & 102,2 & 10443,1 & 1,74 & $-4276,1$ & 18284710,5 & 0,64 \\
\hline Donetsk & $-146,7$ & 21523,3 & 0,33 & $-9894,8$ & 97906324,93 & 0,16 \\
\hline Zhytomyr & $-10,8$ & 116,8 & 1,10 & 1374,2 & 1888528,706 & 1,13 \\
\hline Zacarpattia & $-163,7$ & 26800,4 & 0,24 & $-9769,3$ & 95438489,79 & 0,17 \\
\hline Zaporizhzhia & $-171,8$ & 29518,1 & 0,19 & $-10052,6$ & 101054012,8 & 0,14 \\
\hline Ivano-Frankivsk & $-162,7$ & 26474,0 & 0,24 & $-8208,0$ & 67370648,4 & 0,30 \\
\hline Kyiv & 137,2 & 18821,6 & 1,94 & 5709,4 & 32597676,57 & 1,51 \\
\hline Kirovohrad & 176,8 & 31255,3 & 2,17 & $-1220,4$ & 1489284,631 & 0,91 \\
\hline Lugansk & $-142,5$ & 20308,6 & 0,36 & $-9841,8$ & 96860289,11 & 0,16 \\
\hline Lviv & $-164,2$ & 26964,4 & 0,23 & $-8296,3$ & 68827971,47 & 0,29 \\
\hline Mykolaiv & $-92,5$ & 8557,8 & 0,64 & $-8525,0$ & 72674985,63 & 0,27 \\
\hline Odesa & $-71,5$ & 5113,4 & 0,76 & $-7960,1$ & 63362595 & 0,32 \\
\hline Poltava & 445,4 & 198373,7 & 3,69 & 24542,3 & 602326330 & 3,13 \\
\hline Rivne & $-154,1$ & 23749,4 & 0,29 & $-7002,3$ & 49031680,12 & 0,41 \\
\hline Sumy & 210,8 & 44433,1 & 2,36 & 24531,0 & 601771800,8 & 3,13 \\
\hline Ternopil & $-97,0$ & 9410,6 & 0,61 & $-1686,9$ & 2845505,094 & 0,87 \\
\hline Kharkiv & 70,2 & 4926,9 & 1,56 & 2395,0 & 5736204,626 & 1,22 \\
\hline Kherson & $-160,1$ & 25634,7 & 0,26 & $-7998,3$ & 63972203,02 & 0,32 \\
\hline Khmelnytsky & 32,7 & 1068,7 & 1,35 & 11447,5 & 131046114,8 & 2,00 \\
\hline Cherkasy & 201,8 & 40719,9 & 2,31 & 3497,1 & 12229970,69 & 1,31 \\
\hline Chernivtsi & $-151,5$ & 22954,8 & 0,30 & $-8353,2$ & 69775323,75 & 0,29 \\
\hline Chernihiv & 263,0 & 69164,6 & 2,65 & 27421,8 & 751957171,9 & 3,38 \\
\hline \multicolumn{1}{c}{ Sum } & & $\mathbf{7 4 7 4 6 2 , 8}$ & & & $\mathbf{3 2 0 6 9 0 6 6 1 7}$ & \\
\hline & & $\mathbf{1 7 6 , 4 8}$ & & & $\mathbf{1 1 5 5 9 , 4 6}$ & \\
\hline
\end{tabular}

Table 5. Ranking of regions of Ukraine by investment attractiveness of land resources for the production of wheat, legumes and corn in Ukraine in 2020.

\begin{tabular}{|c|l|r|c|}
\hline Number of region & \multicolumn{1}{|c|}{ Name region } & Sum points & Zones investment attractiveness \\
\hline 1 & Sumy & 17,22 & \multirow{3}{*}{ Zone of strategic investment } \\
attractiveness
\end{tabular}




\section{Conclusion}

The study of investment attractiveness of land resources of Ukraine, taking into account the experience of evaluation and prospects for the application of the method of data standardization in Ukraine allowed to formulate conclusions of theoretical and methodological and practical nature, namely:

1. The range of land prices in Ukraine identified as a result of retrospective analysis, taking into account the current value of gold, can range from 74,435 hryvnias to 351,552 hryvnias per hectare. This price range should be used as a guide and starting prices at auctions at the opening of the land market in Ukraine.

2. Disclosure of the content of the method of data standardization for the analysis of investment attractiveness of land resources in terms of regions shows its usefulness in the use of incomparable indicators, but which can be attractive indicators for investors. The selection and formation of statistical indicators in order to analyze the investment attractiveness of individual areas should be based on certain criteria that depend on the interests of the investor.

3. The application of the method of data standardization in the analysis of investment attractiveness of regions of Ukraine for interest in production of cereals and legumes and corn showed that the most promising regions are: Kharkiv, Poltava, Dnipropetrovsk, Vinnytsia, Chernihiv, Sumy and Zaporizhia. The application of the data standardization method has the prospect of deepening in terms of districts using different combinations of indicators, depending on the specific interests of investing in Ukraine and the world.

\section{References}

1. Verkhovna Rada of Ukraine (2019). Draft Law on Amendments to the Land Code of Ukraine and other legislative acts on improving the system of management and deregulation in the field of land relations. http://w1.c1.rada.gov.ua/pls/zweb2/webproc4 1?pf3511=66970

2. Land Code of Ukraine. (2002). Vidomosti Verkhovnoi Rady Ukrainy (VVR), (3-4), 27. https://zakon.rada.gov.ua/laws/show/2768-14.

3. Verkhovna Rada of Ukraine (2004). Law of Ukraine "On Land Estimating". https://zakon.rada.gov.ua/laws/show/1378-15

4. Agravery (2021). Last year, the investment crisis in the agri-food sectors of the economy reached the level of 2009. https://agravery.com/uk/posts/show/minuloricinvesticijna-kriza-v-agroprodovolcih-sektorah-ekonomiki-dosagla-rivna-2009-roku

5. Palamarchuk, L.V. (2012) Land mortgage: historical experience and problems of the present. Kyiv: Medinform.

6. Riasnianska, A.M. (2015). World experience in land ownership formation. Global and national problems of economy, (7), 58-62.

7. Kucher, A.V. (2018). Methodical bases of estimation of investment attractiveness of land uses of agricultural enterprises. Bulletin of economic science of Ukraine, (1), 7785 .

8. Shvets, V., Shevtsiv, L., Mishchuk, N., Melnyk, B., Humen, Y., \& Mudrak, M. (2020). Investment Attractiveness of Land Resources of Ukraine. 10th International Conference on Advanced Computer Information Technologies (ACIT), Deggendorf, Germany. https://doi.org/10.1109/ACIT49673.2020.9208869 
9. Mamul, L.O. \& Cherniavska, T.A. (2015). New methodological approaches to the analysis of investment attractiveness of regions. Bulletin of economic science of Ukraine, 1 (7), 83-89.

10. Data on valuations of land property (1915). Information on the valuation of Russian private land banks for the years 1903-1912. Petrograd: Edition of periodicals of the Ministry of Finance.

11. State Statistics Service of Ukraine (2020). Production volume, yield and harvested area of crops by species by region as of December 01 (2020). http://www.ukrstat.gov.ua

12. National Bank of Ukraine (2021). Accounting price of bank metals (24.03.2021). https://bank.gov.ua/ua/markets/exchangerates-metal 